\title{
HOTAIR Long Non-coding RNA: Characterizing the Locus Features by the In Silico Approaches
}

\author{
Mohammadreza Hajjari*, Saghar Rahnama \\ Department of Genetics, Shahid Chamran University of Ahvaz, Ahvaz 61336-3337, Iran
}

\begin{abstract}
HOTAIR is an IncRNA that has been known to have an oncogenic role in different cancers. There is limited knowledge of genetic and epigenetic elements and their interactions for the gene encoding HOTAIR. Therefore, understanding the molecular mechanism and its regulation remains to be challenging. We used different in silico analyses to find genetic and epigenetic elements of HOTAIR gene to gain insight into its regulation. We reported different regulatory elements including canonical promoters, transcription start sites, CpGls as well as epigenetic marks that are potentially involved in the regulation of HOTAIR gene expression. We identified repeat sequences and single nucleotide polymorphisms that are located within or next to the CpGls of HOTAIR. Our analyses may help to find potential interactions between genetic and epigenetic elements of HOTAIR gene in the human tissues and show opportunities and limitations for researches on HOTAIR gene in future studies.
\end{abstract}

Keywords: bioinformatics, CpG Islands, epigenetics, gene expression, HOTAIR

\section{Introduction}

It has been estimated that about $1.5 \%$ of human genomic DNA can be annotated as protein coding sequences [1]. So, more than $98 \%$ of the human genome does not encode protein $[2,3]$. However, a large proportion of the genome transcribes non-coding RNAs such as miRNAs and long non-coding RNAs (lncRNAs) [4, 5]. LncRNAs have important roles in different cellular and molecular mechanisms [6]. These long RNAs regulate the activity and position of epigenetic machinery during cell function and segregation [7]. In fact, some of the lncRNAs can recruit catalytic activity of chromatin-modifying proteins [8]. Dysregulation of IncRNAs has been also reported in cancer initiation and progression. However, the molecular mechanism and regulation of these RNAs have been remained to be unknown $[9,10]$.

Rinn et al. [11] identified HOTAIR lncRNA with a $2.2 \mathrm{~kb}$ length. HOTAIR gene is located in a region between HOX11 and HOX12 on chromosome 12q13.3 [12-16]. HOTAIR lncRNA binds to both polycomb repressive complex 2 (PRC2) and lysine specific demethylase 1 (LSD1) complexes, through its 5'-3' domains and directs them to HOXD gene cluster as well as other genes in order to increase gene silencing by coupling the histone $\mathrm{H} 3 \mathrm{~K} 27$ trimethylation and H3K4 demethylation [17, 18].

HOTAIR is an oncogene RNA that is known to have potential role in several cancers. Its overexpression is reported in different solid tumors such as breast, gastric, and colorectal tumors $[19,20]$. The oncogenic role of HOTAIR is reported in different mechanisms such as cell proliferation, invasion, aggression, and metastasis of the tumor cells as well as inhibition of apoptosis [3, 21-25]. In spite of different reports on the potential oncogenic role of HOTAIR, the molecular regulation of this gene needs to be revealed by more studies.

Since the genetic and epigenetic complexities of the HOTAIR locus have not been characterized yet, we aimed to provide an integration data to highlight different compositional features of HOTAIR gene. The potential model may help to design future studies to reveal the molecular mechanisms of this lncRNA. In this study, we highlighted and described a number of features in HOTAIR locus, which may be involved in regulation of this gene. The integrated report is derived from the in silico approaches through different databases and software. 


\section{Methods}

Different databases and bioinformatics software were used. Then, the data were reanalyzed and integrated in order to provide a potential model for describing the genetic and epigenetic features of the HOTAIR locus. Table 1 shows list of the in silico tools used in this study and the methodology is represented as a flowchart (Fig. 1). In our analyses, the desired sequence was mostly defined as a sequence that spans from $2 \mathrm{~kb}$ upstream of annotated transcription start site (TSS) of HOTAIR to the end of the gene. The selection was based on the previous studies defining putative promoter regions from $-2 \mathrm{~kb}$ to $+1 \mathrm{~kb}$ of the TSS [26]. Some data were analyzed through Encyclopedia of DNA
Elements (ENCODE) project cited in University of California, Santa Cruz (UCSC) genome browser. Encode is a genome-wide consortium project with the aim of cataloging all functional elements in the human genome through related experimental conditions. In addition, all of the software was run with default parameters and criteria. The description of each software and database as well as their criteria of the analyses are described in below.

Table 1. Softwares and databases utilized in this article

\begin{tabular}{|c|c|c|c|c|}
\hline \multicolumn{2}{|c|}{ Type of analysis } & \multirow[b]{2}{*}{ Usage } & \multirow[b]{2}{*}{ Software/database } & \multirow[b]{2}{*}{ Reference/address } \\
\hline $\begin{array}{l}\text { Genetic } \\
\text { features }\end{array}$ & $\begin{array}{l}\text { Epigenetic } \\
\text { features }\end{array}$ & & & \\
\hline $\mathrm{O}$ & $\mathrm{O}$ & $\begin{array}{l}\text { Finding different } \\
\text { transcripts }\end{array}$ & $\begin{array}{l}\text { Ace view } \\
\text { UCSC } \\
\text { Ensembl }\end{array}$ & $\begin{array}{l}\text { https://www.ncbi.nlm.nih.gov/ieb/research/acembly/ } \\
\text { http://genome.ucsc.edu/ } \\
\text { http://www.ensembl.org }\end{array}$ \\
\hline $\mathrm{O}$ & - & Promoter detection & $\begin{array}{l}\text { HMM } \\
\text { Promoter scan } \\
\text { Promoter } 2.0 \\
\text { Ensembl } \\
\text { Ace view }\end{array}$ & $\begin{array}{l}\text { http://genome.ucsc.edu/ } \\
\text { https://www-bimas.cit.nih.gov/molbio/proscan/ } \\
\text { http://www.cbs.dtu.dk/services/Promoter/ } \\
\text { http://www.ensembl.org } \\
\text { https://www.ncbi.nlm.nih.gov/ieb/research/acembly/ }\end{array}$ \\
\hline $\mathrm{O}$ & - & $\begin{array}{l}\text { Alternative transcription } \\
\text { start sites }\end{array}$ & $\begin{array}{l}\text { Eponine } \\
\text { SwitchGear }\end{array}$ & $\begin{array}{l}\text { http://genome.ucsc.edu/ } \\
\text { http://genome.ucsc.edu/ }\end{array}$ \\
\hline $\mathrm{O}$ & - & CpGls detection & $\begin{array}{l}\text { UCSC } \\
\text { Bona fides CGls } \\
\text { CpGProD } \\
\text { Weizmann evolutionary } \\
\text { CGls }\end{array}$ & $\begin{array}{l}\text { http://genome.ucsc.edu/ } \\
\text { http://epigraph.mpi-inf.mpg.dedownloadCpG_islands revisited } \\
\text { http://doua.prabi.fr/software/cpgprod } \\
\text { http://genome.ucsc.edu/ }\end{array}$ \\
\hline $\mathrm{O}$ & - & $\begin{array}{l}\text { DNase I hypersensitivity } \\
\text { peak clusters }\end{array}$ & UCSC & http://genome.ucsc.edu/ \\
\hline- & $\mathrm{O}$ & $\begin{array}{l}\text { CpGls methylation } \\
\text { status }\end{array}$ & ENCODE & http://genome.ucsc.edu/ \\
\hline $\mathrm{O}$ & $\mathrm{O}$ & $\begin{array}{l}\text { Gene expression } \\
\text { analysis }\end{array}$ & $\begin{array}{l}\text { Ace view } \\
\text { GTEX RNA-SEQ }\end{array}$ & $\begin{array}{l}\text { https://www.ncbi.nlm.nih.gov/ieb/research/acembly/ } \\
\text { http://genome.ucsc.edu/ }\end{array}$ \\
\hline $\mathrm{O}$ & $\mathrm{O}$ & Finding $\mathrm{CTCF}$ & ENCODE & http://genome.ucsc.edu \\
\hline $\mathrm{O}$ & - & Finding motifs & $\begin{array}{l}\text { MEME } \\
\text { Mast program }\end{array}$ & $\begin{array}{l}\text { http://MEME-Suite.org/ } \\
\text { http://MEME-Suite.org/ }\end{array}$ \\
\hline $\mathrm{O}$ & $\mathrm{O}$ & $\begin{array}{l}\text { Transcription factor } \\
\text { binding sites }\end{array}$ & PreMode & http://genomequebec.mcgill.ca/PReMod// \\
\hline $\mathrm{O}$ & - & Detection of enhancers & HMM & http://genome.ucsc.edu/ \\
\hline $\mathrm{O}$ & - & $\begin{array}{l}\text { Finding repeated } \\
\text { sequences }\end{array}$ & $\begin{array}{l}\text { Repeat masker } \\
\text { Tandem repeat by TRF }\end{array}$ & $\begin{array}{l}\text { http://genome.ucsc.edu/ } \\
\text { http://genome.ucsc.edu/ }\end{array}$ \\
\hline $\mathrm{O}$ & - & $\begin{array}{l}\text { Single nucleotide } \\
\text { polymorphism }\end{array}$ & $\mathrm{dbSNP}$ & http://genome.ucsc.edu/ \\
\hline- & $\mathrm{O}$ & $\begin{array}{l}\text { Detection of histone } \\
\text { marks }\end{array}$ & UCSC & http://genome.ucsc.edu/ \\
\hline
\end{tabular}

UCSC, University of California, Santa Cruz; HMM, Hidden Markov Model; CGI, CpG Island; ENCODE, Encyclopedia of DNA Elements; TRF, tandem repeat finder. 


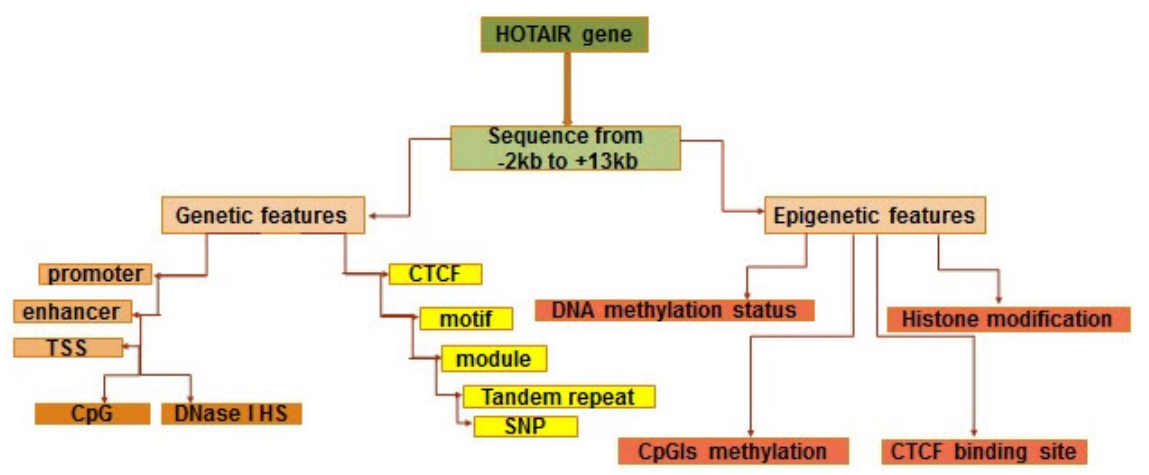

GENCODEV22 general transcription set

$$
\text { HOTAIR }
$$

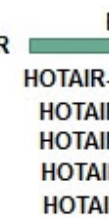

E7 E6 E5 E4

(1)

HOTAIR

HOTAIR

NR_047518.1
NR_047517.1

NR_003716.3
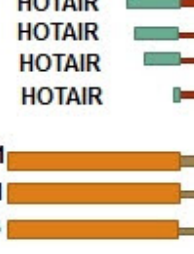

(ENST00000424518.5)

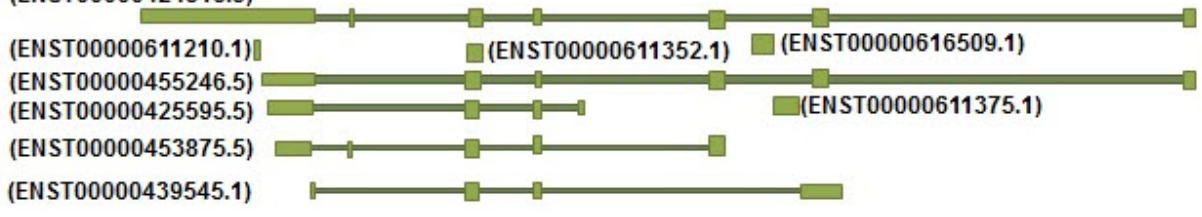

Fig. 1. The flowchart of the methods used in the study. TSS, transcription start site; SNP, single nucleotide polymorphism.
Fig. 2. Transcript variants of HOTAIR gene derived from the GENCODE, Ensemble and Refseq.

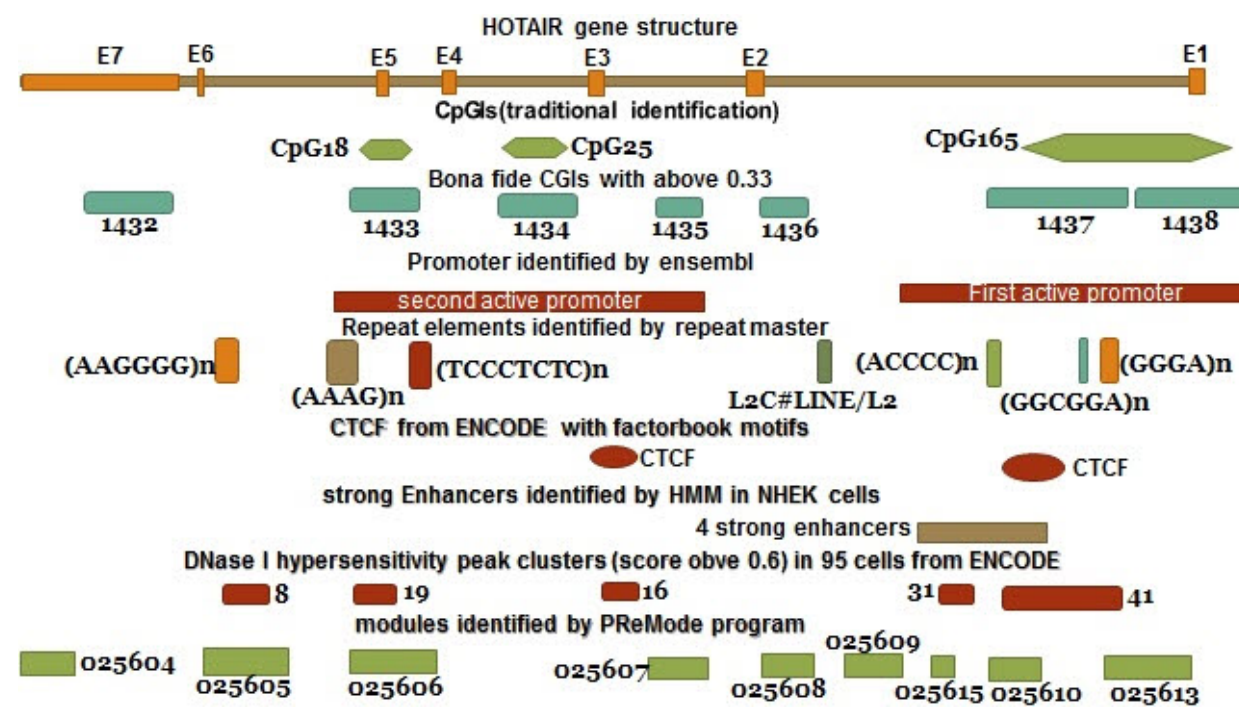

Fig. 3. Integrated regulatory elements of HOTAIR gene structure. The schematic diagram shows a summary of results from different databases and software which are described in the text. 


\section{Results}

\section{HOTAIR gene is transcribed into different RNA isoforms by alternative compositional features}

According to the Ace view database, 11 distinct GT-AG introns are identified in the HOTAIR gene. This results in seven different transcripts, six of which are created through alternative splicing (https://www.ncbi.nlm.nih.gov/ieb/ research/acembly/). Different variants were found in GENECODE V22 and Ensembl. According to the Refseq, there are three transcript variants for this gene (NR 047518.1, NR_047517.1 and NR_003716.3) (Fig. 2).

Since it seems that alternative transcripts of HOTAIR are due to alternative promoters, TSSs, alternative polyadenylation sites, and alternative splicing, we tried to find different promoters, TSSs, polyadenylation, and splice sites in the HOTAIR gene.

We found alternative promoters and polyadenylation sites in the HOTAIR locus (https://www.ncbi.nlm.nih.gov/ieb/ research/acembly/). According to the Ensembl, there are two active promoters in this gene (Fig. 3). Also, Chromatin state segmentation using Hidden Markov Model (HMM) [27] identified these two active promoters as well as enhancers in the HOTAIR gene in some cell lines. The HMM is a probabilistic model representing probability distributions over sequences of observations. Supplementary Table 1 which is based on UCSC hg19, shows the positions of the active promoters of HOTAIR locus in Ensemble and HMM.

Promoter prediction with different tools recognized alternative promoters throughout this gene. Promoter scan program was run with the default promoter cutoff score. This program predicts promoters based on the degree of homologies with eukaryotic RNA pol II promoter sequences (https://www-bimas.cit.nih.gov/molbio/proscan/) [28]. Different TSSs were also found in the HOTAIR gene by different programs and software including Eponine, Switchgear, and Promoter 2 [29]. The Eponine program provides a probabilistic method for detecting TSSs. The Switchgear algorithm uses a scoring metric based largely on existing transcript evidence. Promoter 2 takes advantage of a combination of principles that are common to neural networks and genetic algorithms. The positions of found TSSs compared to other features are shown in the Supplementary Table 1.

\section{CpG islands were found to be overlapped with active promoters and DNase I hypersensitivity sites}

According to the UCSC browser, bona fide CpGIs, Weizmann Evolutionary, and CpG ProD program, there were different CpG Islands (CGIs) in the HOTAIR gene. These CpGIs are shown in the Fig. 4. UCSC genome browser identifies CGIs of human genome based on the regions of DNA with average $(\mathrm{G}+\mathrm{C})$ content greater than $50 \%$, length greater than $200 \mathrm{bp}$ and a moving average $\mathrm{CpG} \mathrm{O} / \mathrm{E}$ greater than $0.6[30,31]$. "Bona fide" identifies functional CpGIs by linking genetic and epigenetic information [32]. Weizmann evolutionary (WE) predicts highly conserved CGIs through their classification of evolutionary dynamics (http://genome. ucsc.edu/) [33]. "CpG ProD" program identifies CpGIs-overlapping with promoters in the large genomic regions under analysis and shows these CpGIs with length longer than other CpGIs [34]. Then, we tried to find any overlap between CpGIs and other regulatory elements. Two TSSs (CHR12-P0397-R1, CHR12-P0397-R2) were found within CpG165 (annotated in UCSC genome browser) and 1437 (derived

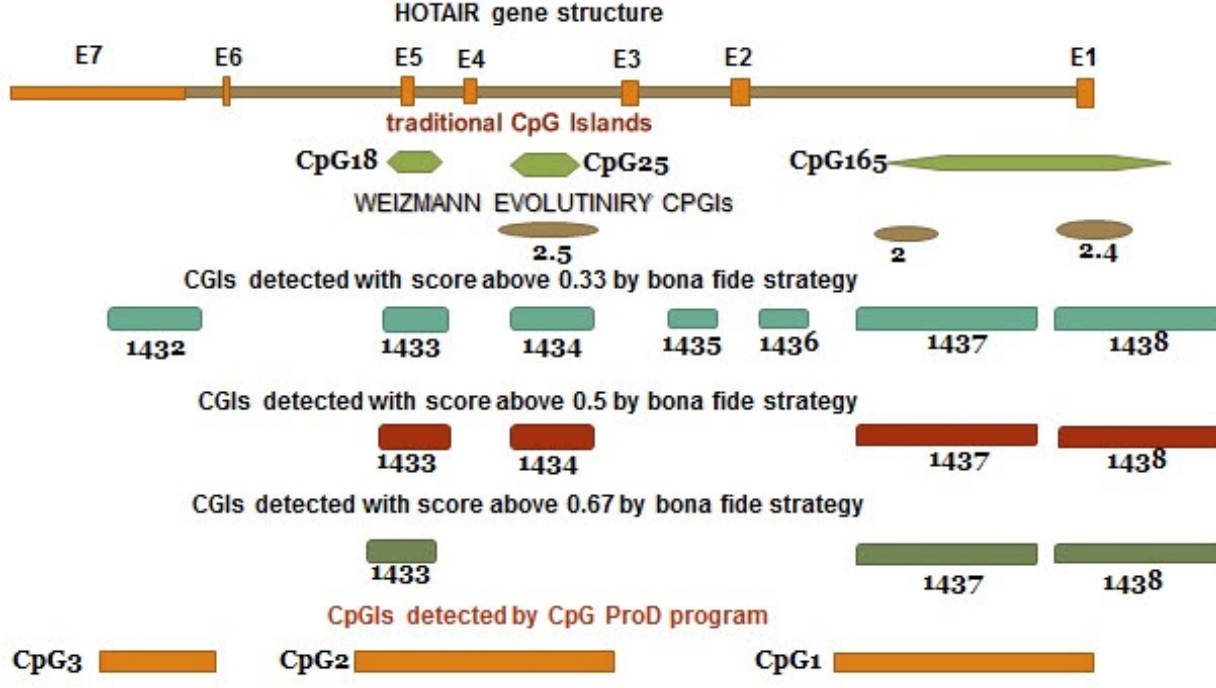

Fig. 4. CpG Islands in the HOTAIR gene. The data are derived from databases and prediction software. CGI, CpG Island. 
Table 2. The positions of regulatory sequences which are near or within CpG165 of HOTA/R

\begin{tabular}{|c|c|c|c|c|c|c|c|}
\hline $\begin{array}{l}\text { Position of } \\
\text { CpG165 }\end{array}$ & $\begin{array}{l}\text { Promoter } \\
\text { (active) }\end{array}$ & Other CpGls & $\begin{array}{l}\text { Tandem repeat } \\
(\text { strand }+)\end{array}$ & CTCF & Strong enhancer & $\begin{array}{c}\text { DNase I } \\
\text { hypersensitivity }\end{array}$ & $\begin{array}{c}\text { Module and } \\
\text { TSSs }\end{array}$ \\
\hline \multirow[t]{5}{*}{$\begin{array}{l}\text { CpG165: } 543- \\
66816-543691 \\
03\end{array}$} & $\begin{array}{l}\text { HSMM cells: } \\
54365934-54 \\
370733\end{array}$ & $\begin{array}{l}\text { Bona fide } \\
\text { 1437: } \\
54366623-54 \\
367999\end{array}$ & $\begin{array}{l}\text { (GGCGGA)n: } \\
54367601-54 \\
367637\end{array}$ & $\begin{array}{r}54366799- \\
54367314\end{array}$ & $\begin{array}{l}\text { NHEK cells: } \\
4 \text { strong } \\
\text { enhancers: } \\
54365934-54 \\
367133\end{array}$ & $\begin{array}{l}\text { 41: } 54366785- \\
\text { 54367814 }\end{array}$ & $\begin{array}{l}\text { 025610: } \\
54366634-54 \\
366977\end{array}$ \\
\hline & $\begin{array}{l}\text { NHEK cells: } \\
54367139-54 \\
369133\end{array}$ & $\begin{array}{l}\text { CpG2 (WE): } \\
54366684-54 \\
366909\end{array}$ & $\begin{array}{l}\text { (GGGA)n: } \\
54367731-54 \\
367801\end{array}$ & & & $\begin{array}{l}\text { NHEK cells } \\
\text { DNase I hots- } \\
\text { pot: } 75095: \\
54366045-54 \\
370999\end{array}$ & $\begin{array}{l}\text { 025613: } \\
54367707-54 \\
368584\end{array}$ \\
\hline & $\begin{array}{l}\text { First active } \\
\text { promoter } \\
\text { based on } \\
\text { ensembl: } \\
54365691-54 \\
370092\end{array}$ & $\begin{array}{l}\text { CpG1 } \\
\text { (CpGProD): } \\
54366456-54 \\
368740\end{array}$ & $\begin{array}{l}\frac{\text { GAGGGAGG }}{\text { GAGCGAGA: }} \\
54367742-54 \\
367783\end{array}$ & & & & $\begin{array}{l}\text { TSSs: } \\
\text { CHR12-P039 } \\
\text { 7-R1: } \\
\text { 54366912-54 } \\
366912\end{array}$ \\
\hline & & $\begin{array}{l}\text { CpG2.4 (WE): } \\
54368334-54 \\
368964\end{array}$ & & & & & $\begin{array}{l}\text { CHR12-P0397- } \\
\text { R2: } 54367584 \\
54367584\end{array}$ \\
\hline & & $\begin{array}{l}\text { Bona fide } \\
\text { 1438: } \\
54368166-54 \\
369840\end{array}$ & & & & & \\
\hline
\end{tabular}

Positions are based on UCSC hg19.

TSS, transcription start site; WE, Weizmann evolutionary.

from bona fide CGIs). The CpGIs were mostly overlapped with the active promoter regions (Fig. 3, Supplementary Table 1). We focused on CpG165 and found some regulatory elements which are within or near to this CpG (Table 2).

In addition, several DNase I hypersensitivity hotspots were found to be overlapped with CpGIs in some cell lines (Supplementary Table 1). We found the DNase I hypersensitivity peak clusters of HOTAIR gene in 95 cells with score greater than 0.6 by using UCSC genome browser. DNase I hypersensitivity peak cluster 19 is located within CpG1433 and mostly overlaps with CpG18. Also, DNase I hypersensitivity peak cluster 41 is located within CpG1437 and mostly overlaps with CpG165 and partially overlaps with CpG2 (WE) (Fig. 3, Supplementary Table 1).

Furthermore, we detected specific $\mathrm{CpG}$ dinucleotides methylation status within or near the predicted CpGIs in some cell lines by using ENCODE (Supplementary Table 2). This track identifies specific $\mathrm{CpG}$ dinucleotides methylation status by Infinium human methylation 450 bead array platform and classifies the methylation status into four groups: (1) not available (score $=0)$, (2) unmethylated $(0<$ score $\leq 200)$, (3) partially methylated ( $200<$ score $<600)$, and (4) methylated (score $\geq 600$ ) (http://genome.ucsc.edu/).

\section{CTCF and transcription factor binding sites are overlapped with CpGls and TSSs}

GTEx RNA-seq strategy indicates that HOTAIR has variable expression in different tissues and its most expression level is in the artery-tibial tissue (data not shown). We found two putative regions for CTCF binding sites in the HOTAIR locus by ENCODE with factorbook motifs, one of which is located within CpG1437 (bona fide CpGIs) and mostly overlaps with CpG165 (Table 2, Fig. 3). This track determines regions of transcription factor binding sites taken from a comprehensive chip-seq experiments identified by ENCODE and factorbook pool (http://genome. ucsc.edu/). We predicted sequences of motifs and positions of these motifs in the HOTAIR locus by using MEME and MAST programs (Supplementary Table 3). MEME program searches the motifs from downloaded sequences through using complementary strengths of probabilistic and discrete models (http://MEME-Suite.org/) [35, 36]. The program was run with default parameters and normal mode of motif discovery. Mast program searches specific sequences based on predicted motifs by MEME program and exactly matches these sequences with the motifs sequences (http:// MEME-Suite.org/) [37].

We found nine sequences of modules depending on their 
transcription factor binding sites in the HOTAIR locus by PReMode program $[38,39]$. We observed some of these elements overlapped with the predicted CpGIs and TSSs (Fig. 3, Supplementary Table 1). In addition, we determined that some of these modules have common transcription factors (data not shown).

\section{Some polymorphisms such as tandem repeats exist within the regulatory elements}

Repeat Masker found several repeats sequences overlapped with regulatory elements of the HOTAIR locus such as CpGIs (Fig. 3, Supplementary Table 1) and motifs (Supplementary Table 3). Repeat master investigates query sequences and generates a detailed annotation of available repeats in these sequences and shows dispersed repeats and low complexity DNA sequences (http://genome.ucsc.edu/). In addition, tandem repeat finder, which analyzes simple tandem repeats, predicted one simple tandem repeat (GAGGGAGGGAGCGAGA) within this gene (Supplementary Table 1) (http://genome.ucsc.edu/) [40]. In addition, we found some simple nucleotide polymorphisms within regulatory sequences of HOTAIR gene (Supplementary Table 4).

\section{Discussion}

Studies have shown that aberrant epigenetic modifications including aberrant DNA methylation and histone modification are significantly involved in the dysregulation of genes with their potential roles in cancers [41]. However, identification of the exact elements of HOTAIR as well as their interaction has not been discovered yet. This study was aimed to find and highlight different regulatory elements by data integration. We identified putative regulatory elements that contribute to the regulation of HOTAIR expression by in silico analyses. Identification of these elements suggests new understanding of HOTAIR expression and might help to design future studies on this lncRNA which has oncogenic role in different cancers [42-45].

First, we tried to show different isoforms of HOTAIR RNA transcribed through alternative mechanisms. Since a recent study suggested the important role of HOTAIR domains in its function [46], we propose studying the molecular roles of different RNA isoforms in future researches. Then, in order to find alternative and potential features involved in generation of RNA isoforms, we checked the putative TSSs, promoters, and polyadenylation sites. We found different features, which are potentially involved in alternative transcription of HOTAIR gene.

Considering the potential involvement of methylation beyond CGI-promoters in human cancer, we focused on potential CGIs of HOTAIR. According to the fact that function of DNA methylation seems to be varied with context, we tried to find any relation between the CGIs and other compositional features such as TSSs, promoters, enhancers, DNase I hypersensitivity sites, and CTCF binding sites. Alterations in DNA methylation are known to cooperate with genetic elements and to be involved in human carcinogenesis. The results showed different CpGIs in the HOTAIR locus and determined their epigenetic status through integration analysis. The methylation status of these CGIs needs to be revealed in future researches. The methylation analysis will be so important because we currently know that most CGIs located in TSSs are not methylated. However, CGI methylation of the TSS is associated with long-term silencing. In addition, CGIs in gene bodies are sometimes methylated in a tissue-specific manner [47]. It has been reported that methylation of a CTCF-binding site may block the binding of CTCF. Altogether, different CpGIs overlapped with genetic elements seem to have important roles in controlling HOTAIR.

Some repeat sequences and single nucleotide polymorphisms exist within or next to the predicted CpGIs. We think that repeat number variations may effect on methylation status of regulatory regions of HOTAIR gene. Different studies reported some associations between polymorphisms of HOTAIR and cancers risks. The examples are the association between rs920778 [48], rs4759314 [49], and rs12826786 [25] and gastric cancer, rs7958904 and colorectal cancer [50], rs920788 and breast cancer [51], rs4759314 and rs7958904 in epithelial ovarian cancer [52]. We found that some SNPs are located within regulatory regions and so may effect on the gene expression. Also, since the repeat sequences of HOTAIR gene might contribute to the methylation status of regulatory regions, we highlighted the overlaps between these sequences and the predicted CpGIs.

Due to the overlap with active promoter, strong enhancer, CTCF binding site, DNase I hypersensitive sites, SNPs, and repeat sequences, CpG165 seems to be more important compared to other CpGIs for generation of the long RNA isoform. However, according to the Fig. 3, considering the overlap with other structural features, other CpGIs within the gene structure also seems to be involved in gene regulation. This integration model should be checked and validated in future experimental works.

Altogether, it seems that alternative transcripts of HOTAIR originate from interactions between genetic and epigenetic elements. Our data provide strong evidence based on the databases and in silico prediction that specific sequence motifs may potentially be involved in DNA methylation states of various set of CGIs in different tissues including normal and tumors. Our study suggests that the combinatorial binding of specific transcription factors plays a 
major role in regulation of HOTAIR expression. Future work that aims to provide detailed maps of epigenome in normal and diseased states is crucial to our understanding of HOTAIR role in cancer pathogenesis.

ORCID: Mohammadreza Hajjari: http://orcid.org/00000003-3838-0259; Saghar Rahnama: http://orcid.org/00000002-2068-5436

\section{Authors' contribution}

Conceptualization: $\mathrm{MH}$

Formal analysis: SR, MH

Methodology: $\mathrm{MH}$

Visualization: $\mathrm{MH}, \mathrm{SR}$

Writing - original draft: SR, MH

Review and edit: $\mathrm{MH}$

\section{Acknowledgments}

This study was conducted and supported as a project in Shahid Chamran Universty of Ahvaz.

\section{Supplementary materials}

Supplementary data including four tables can be found with this article online at http://www.genominfo.org/src/sm/ gni-15-170-s001.pdf.

\section{References}

1. Harrow J, Frankish A, Gonzalez JM, Tapanari E, Diekhans M, Kokocinski F, et al. GENCODE: the reference human genome annotation for The ENCODE Project. Genome Res 2012;22: 1760-1774.

2. Kapranov P, Cheng J, Dike S, Nix DA, Duttagupta R, Willingham AT, et al. RNA maps reveal new RNA classes and a possible function for pervasive transcription. Science 2007;316:1484-1488.

3. Hajjari M, Salavaty A. HOTAIR: an oncogenic long non-coding RNA in different cancers. Cancer Biol Med 2015;12:1-9.

4. Fatica A, Bozzoni I. Long non-coding RNAs: new players in cell differentiation and development. Nat Rev Genet 2014;15: 7-21.

5. Yu X, Li Z. Long non-coding RNA HOTAIR: a novel oncogene (review). Mol Med Rep 2015;12:5611-5618.

6. Khandelwal A, Malhotra A, Jain M, Vasquez KM, Jain A. The emerging role of long non-coding RNA in gallbladder cancer pathogenesis. Biochimie 2017;132:152-160.

7. Rinn JL. lncRNAs: linking RNA to chromatin. Cold Spring Harb Perspect Biol 2014;6:a018614.

8. Mercer TR, Mattick JS. Structure and function of long noncoding RNAs in epigenetic regulation. Nat Struct Mol Biol
2013;20:300-307.

9. $\mathrm{Li} \mathrm{CH}$, Chen Y. Targeting long non-coding RNAs in cancers: progress and prospects. Int J Biochem Cell Biol 2013;45: 1895-1910.

10. Ishibashi M, Kogo R, Shibata K, Sawada G, Takahashi Y, Kurashige J, et al. Clinical significance of the expression of long non-coding RNA HOTAIR in primary hepatocellular carcinoma. Oncol Rep 2013;29:946-950.

11. Rinn JL, Kertesz M, Wang JK, Squazzo SL, Xu X, Brugmann $\mathrm{SA}$, et al. Functional demarcation of active and silent chromatin domains in human HOX loci by noncoding RNAs. Cell 2007;129:1311-1323.

12. Loewen G, Zhuo Y, Zhuang Y, Jayawickramarajah J, Shan B. lincRNA HOTAIR as a novel promoter of cancer progression. J Can Res Updates 2014;3:134-140.

13. Bhan A, Mandal SS. Estradiol-induced transcriptional regulation of long non-coding RNA, HOTAIR. Methods Mol Biol 2016;1366:395-412.

14. He S, Liu S, Zhu H. The sequence, structure and evolutionary features of HOTAIR in mammals. BMC Evol Biol 2011;11:102.

15. Zhang J, Zhang P, Wang L, Piao HL, Ma L. Long non-coding RNA HOTAIR in carcinogenesis and metastasis. Acta Biochim Biophys Sin (Shanghai) 2014;46:1-5.

16. Schorderet P, Duboule D. Structural and functional differences in the long non-coding RNA hotair in mouse and human. PLoS Genet 2011;7:e1002071.

17. Tsai MC, Manor O, Wan Y, Mosammaparast N, Wang JK, Lan $\mathrm{F}$, et al. Long noncoding RNA as modular scaffold of histone modification complexes. Science 2010;329:689-693.

18. Meredith EK, Balas MM, Sindy K, Haislop K, Johnson AM. An RNA matchmaker protein regulates the activity of the long noncoding RNA HOTAIR. RNA 2016;22:995-1010.

19. Ma MZ, Li CX, Zhang Y, Weng MZ, Zhang MD, Qin YY, et al. Long non-coding RNA HOTAIR, a c-Myc activated driver of malignancy, negatively regulates miRNA-130a in gallbladder cancer. Mol Cancer 2014;13:156.

20. Wu Y, Zhang L, Wang Y, Li H, Ren X, Wei F, et al. Long noncoding RNA HOTAIR involvement in cancer. Tumour Biol 2014;35:9531-9538.

21. Berrondo C, Flax J, Kucherov V, Siebert A, Osinski T, Rosenberg A, et al. Expression of the long non-coding RNA HOTAIR correlates with disease progression in bladder cancer and is contained in bladder cancer patient urinary exosomes. PLoS One 2016;11:e0147236.

22. Kim HJ, Lee DW, Yim GW, Nam EJ, Kim S, Kim SW, et al. Long non-coding RNA HOTAIR is associated with human cervical cancer progression. Int J Oncol 2015;46:521-530.

23. Li J, Yang S, Su N, Wang Y, Yu J, Qiu H, et al. Overexpression of long non-coding RNA HOTAIR leads to chemoresistance by activating the Wnt/beta-catenin pathway in human ovarian cancer. Tumour Biol 2016;37:2057-2065.

24. Chiyomaru T, Fukuhara S, Saini S, Majid S, Deng G, Shahryari $\mathrm{V}$, et al. Long non-coding RNA HOTAIR is targeted and regulated by miR-141 in human cancer cells. J Biol Chem 2014;289: 12550-12565.

25. Guo W, Dong Z, Bai Y, Guo Y, Shen S, Kuang G, et al. Associations between polymorphisms of HOTAIR and risk of gastric 
cardia adenocarcinoma in a population of north China. Tumour Biol 2015;36:2845-2854.

26. Marino-Ramirez L, Spouge JL, Kanga GC, Landsman D. Statistical analysis of over-represented words in human promoter sequences. Nucleic Acids Res 2004;32:949-958.

27. Pedersen AG, Baldi P, Brunak S, Chauvin Y. Characterization of prokaryotic and eukaryotic promoters using hidden Markov models. Proc Int Conf Intell Syst Mol Biol 1996;4:182-191.

28. Prestridge DS. Predicting Pol II promoter sequences using transcription factor binding sites. J Mol Biol 1995;249:923-932.

29. Down TA, Hubbard TJ. Computational detection and location of transcription start sites in mammalian genomic DNA. Genome Res 2002;12:458-461.

30. Gardiner-Garden M, Frommer M. CpG islands in vertebrate genomes. J Mol Biol 1987;196:261-282.

31. Boucher CA, King SK, Carey N, Krahe R, Winchester CL, Rahman $\mathrm{S}$, et al. A novel homeodomain-encoding gene is associated with a large $\mathrm{CpG}$ island interrupted by the myotonic dystrophy unstable (CTG)n repeat. Hum Mol Genet 1995;4: 1919-1925.

32. Bock C, Walter J, Paulsen M, Lengauer T. CpG island mapping by epigenome prediction. PLoS Comput Biol 2007;3:e110.

33. Hajjari M, Khoshnevisan A, Lemos B. Characterizing the retinoblastoma 1 locus: putative elements for Rb1 regulation by in silico analysis. Front Genet 2014;5:2.

34. Ponger L, Mouchiroud D. CpGProD: identifying CpG islands associated with transcription start sites in large genomic mammalian sequences. Bioinformatics 2002;18:631-633.

35. Wang Z, Fan H, Yang HH, Hu Y, Buetow KH, Lee MP. Comparative sequence analysis of imprinted genes between human and mouse to reveal imprinting signatures. Genomics 2004;83:395-401.

36. Hajjari M, Behmanesh M, Jahani MM. In silico finding of putative cis-acting elements for the tethering of polycomb repressive complex2 in human genome. Bioinformation 2014; 10:187-190.

37. Janssen CS, Phillips RS, Turner CM, Barrett MP. Plasmodium interspersed repeats: the major multigene superfamily of malaria parasites. Nucleic Acids Res 2004;32:5712-5720.

38. Jeziorska DM, Jordan KW, Vance KW. A systems biology approach to understanding cis-regulatory module function. Semin Cell Dev Biol 2009;20:856-862.

39. Ferretti V, Poitras C, Bergeron D, Coulombe B, Robert F, Blanchette M. PReMod: a database of genome-wide mammalian cis-regulatory module predictions. Nucleic Acids Res
2007;35:D122-D126.

40. Benson G. Tandem repeats finder: a program to analyze DNA sequences. Nucleic Acids Res 1999;27:573-580.

41. Suzuki H, Maruyama R, Yamamoto E, Niinuma T, Kai M. Relationship between noncoding RNA dysregulation and epigenetic mechanisms in cancer. In: The Long and Short Non-coding RNAs in Cancer Biology (Song E, ed.). Singapore: Springer, 2016. pp. 109-135.

42. Deng J, Yang M, Jiang R, An N, Wang X, Liu B. Long non-coding RNA HOTAIR regulates the proliferation, self-renewal capacity, tumor formation and migration of the cancer stem-like cell (CSC) subpopulation enriched from breast cancer cells. PLoS One 2017;12:e170860.

43. Kim K, Jutooru I, Chadalapaka G, Johnson G, Frank J, Burghardt R, et al. HOTAIR is a negative prognostic factor and exhibits pro-oncogenic activity in pancreatic cancer. Oncogene 2013;32:1616-1625.

44. Nakagawa T, Endo H, Yokoyama M, Abe J, Tamai K, Tanaka N, et al. Large noncoding RNA HOTAIR enhances aggressive biological behavior and is associated with short disease-free survival in human non-small cell lung cancer. Biochem Biophys Res Commun 2013;436:319-324.

45. Borley J, Brown R. Epigenetic mechanisms and therapeutic targets of chemotherapy resistance in epithelial ovarian cancer. Ann Med 2015;47:359-369.

46. Loewen G, Jayawickramarajah J, Zhuo Y, Shan B. Functions of lncRNA HOTAIR in lung cancer. J Hematol Oncol 2014;7:90.

47. Jones PA. Functions of DNA methylation: islands, start sites, gene bodies and beyond. Nat Rev Genet 2012;13:484-492.

48. Pan W, Liu L, Wei J, Ge Y, Zhang J, Chen $\mathrm{H}$, et al. A functional lncRNA HOTAIR genetic variant contributes to gastric cancer susceptibility. Mol Carcinog 2016;55:90-96.

49. Du M, Wang W, Jin H, Wang Q, Ge Y, Lu J, et al. The association analysis of lncRNA HOTAIR genetic variants and gastric cancer risk in a Chinese population. Oncotarget 2015;6:31255-31262.

50. Xue Y, Gu D, Ma G, Zhu L, Hua Q, Chu H, et al. Genetic variants in lncRNA HOTAIR are associated with risk of colorectal cancer. Mutagenesis 2015;30:303-310.

51. Yan R, Cao J, Song C, Chen Y, Wu Z, Wang K, et al. Polymorphisms in lncRNA HOTAIR and susceptibility to breast cancer in a Chinese population. Cancer Epidemiol 2015;39:978-985.

52. Wu H, Shang X, Shi Y, Yang Z, Zhao J, Yang M, et al. Genetic variants of lncRNA HOTAIR and risk of epithelial ovarian cancer among Chinese women. Oncotarget 2016;7:41047-41052. 


\section{SUPPLEMENTARY INFORMATION}

HOTAIR Long Non-coding RNA: Characterizing the Locus Features by the In Silico Approaches

\section{Mohammadreza Hajjari*, Saghar Rahnama}

Department of Genetics, Shahid Chamran University of Ahvaz, Ahvaz 61336-3337, Iran 
Supplementary Table 1. The positions of regulatory sequences in the HOTAIR locus

\begin{tabular}{|c|c|c|c|c|c|c|c|}
\hline Position & $\begin{array}{l}\text { Promoter } \\
\text { (active) }\end{array}$ & CpGIs & $\begin{array}{l}\text { Tandem repeat } \\
\text { (strand }+ \text { ) }\end{array}$ & CTCF & Enhancer & $\begin{array}{c}\text { DNase I } \\
\text { hypersensitivity }\end{array}$ & $\begin{array}{l}\text { Module } \\
\text { and TSSs }\end{array}$ \\
\hline $\begin{array}{l}54354858- \\
54356533\end{array}$ & No & No & No & No & No & No & $\begin{array}{l}\text { O25604: } \\
54355865- \\
54356303 \\
\text { TSS: } \\
\text { (chr12.11801): } \\
54354858- \\
54354859\end{array}$ \\
\hline $\begin{array}{l}54356534- \\
54359334\end{array}$ & $\begin{array}{l}\text { HSMM cells: } \\
54359134- \\
54359334\end{array}$ & $\begin{array}{l}\text { Bonafide1432: } \\
\text { 54357217-54357921 } \\
\text { CpG3 (CpGProD): } \\
\text { 54357032-54358001 } \\
\text { CpG2 (CpGProD): } \\
\text { 54359256-54359334 }\end{array}$ & $\begin{array}{l}\text { (AAGGGG)n: } \\
54358177- \\
54358291\end{array}$ & No & $\begin{array}{l}\text { HSMM cells: } \\
12 \text { Weak enhancers } \\
\text { HMEC cells: } \\
20 \text { Weak enhancers }\end{array}$ & $\begin{array}{l}\text { 8: } 54358245- \\
54358454 \\
\text { HSMM cells } \\
\text { DNase I } \\
\text { hotspot: } 66574: \\
\text { 54357302-54358901 }\end{array}$ & $\begin{array}{l}\text { O25605: } \\
54358063- \\
54358978\end{array}$ \\
\hline $\begin{array}{l}54359335- \\
54362492\end{array}$ & $\begin{array}{l}\text { HSMM cells: } \\
54359335- \\
54361533 \\
\\
\text { NHEK cells: } \\
54362134- \\
54362333 \\
\\
\text { Second active } \\
\text { promoter } \\
\text { based on } \\
\text { Ensembl: } \\
54359491- \\
54362492\end{array}$ & $\begin{array}{l}\text { CpG18: } \\
\text { 54359659-54359906 } \\
\text { Bonafide1433: } \\
\text { 54359598-54360005 } \\
\text { CpG2.5 (WE): } \\
\text { 54360184-54360883 } \\
\text { CpG25: } \\
\text { 54360375-54360660 } \\
\text { Bonafide1434: } \\
\text { 54360202-54360827 } \\
\text { Bonafide1435: } \\
\text { 54362119-54362323 } \\
\text { CPG2 (CpGProD): } \\
\text { 54359334-54360945 }\end{array}$ & $\begin{array}{l}\text { (AAAG)n: } \\
54359478- \\
54359704 \\
\text { (TCCCTCTC)n: } \\
54359986- \\
54360112\end{array}$ & $\begin{array}{l}54361413- \\
54361642\end{array}$ & $\begin{array}{l}\text { HMEC cells: } \\
19 \text { Weak enhancers }\end{array}$ & $\begin{array}{l}\text { 19: } 54359645- \\
54359854 \\
\text { 16: } 54361465- \\
54361654 \\
\\
\text { HSMM cells } \\
\text { DNase I } \\
\text { hotspot: } 66575: \\
\text { 54359619-54360710 } \\
\text { 66576: } \\
\text { 54361172-54361793 }\end{array}$ & $\begin{array}{l}\text { O25606: } \\
\text { 54359632- } \\
54360527 \\
\text { o25607: } \\
\text { 54361760- } \\
54362456 \\
\text { TSS: } \\
\text { CHR12- } \\
\text { Mo409-R1: } \\
\text { 54361133- } \\
\text { 54361133 }\end{array}$ \\
\hline $\begin{array}{l}54362493- \\
54363334\end{array}$ & No & $\begin{array}{l}\text { Bona fide 1436: } \\
54362691-54362900\end{array}$ & No & No & $\begin{array}{l}\text { HSMM cells: } \\
6 \text { Weak enhancers }\end{array}$ & No & $\begin{array}{l}\text { o256o8: } \\
54362765- \\
54363139\end{array}$ \\
\hline $\begin{array}{l}54363335- \\
54364965\end{array}$ & No & No & $\begin{array}{l}\text { L2C (within } \\
\text { strand-): } \\
54363655- \\
54363707\end{array}$ & No & $\begin{array}{l}\text { HSMM cells: } \\
7 \text { Weak enhancers }\end{array}$ & No & $\begin{array}{l}\text { o25609: } \\
54364519- \\
54364965\end{array}$ \\
\hline $\begin{array}{l}54364966 \\
54370999\end{array}$ & $\begin{array}{l}\text { HSMM cells: } \\
54365934- \\
54370733 \\
\\
\text { NHEK cells: } \\
54367139- \\
54369133 \\
\text { First active } \\
\text { promoter } \\
\text { based on } \\
\text { Ensembl: } \\
54365691- \\
54370092\end{array}$ & $\begin{array}{l}\text { Bona fide 1437: } \\
\text { 54366623-54367999 } \\
\text { CpG2 (WE): } \\
\text { 54366684-54366909 } \\
\text { CpG165: } \\
\text { 54366816-54369103 } \\
\text { CpG1 (CpGProD): } \\
\text { 54366456-54368740 } \\
\text { CpG2.4 (WE): } \\
\text { 54368334-54368964 } \\
\text { Bona fide 1438: } \\
\text { 54368166-54369840 }\end{array}$ & $\begin{array}{l}\text { (ACCCC)n: } \\
54366647- \\
54366670 \\
\text { (GGCGGA)n: } \\
\text { 54367601- } \\
54367637 \\
\text { (GGGA)n: } \\
\text { 54367731- } \\
\text { 54367801 } \\
\text { GAGGGAGGGAGC } \\
\text { GAGA: } \\
\text { 54367742- } \\
\text { 54367783 }\end{array}$ & $\begin{array}{l}54366799 \\
54367314\end{array}$ & $\begin{array}{l}\text { HEpG2 cells: } \\
6 \text { Weak enhancers } \\
\text { HMEC cells: } \\
13 \text { Weak enhancers } \\
\text { HSMM cells: } \\
20 \text { Weak enhancers } \\
\text { NHEK cells: } \\
7 \text { Weak enhancers, } \\
\text { 4 Strong } \\
\text { enhancers: } \\
\text { 54365934- } \\
54367133\end{array}$ & $\begin{array}{l}\text { 31: } 54366145- \\
\text { 54366374 } \\
\text { 41: } 54366785- \\
\text { 54367814 } \\
\text { HSMM cells } \\
\text { DNase I } \\
\text { hotspot: 66579: } \\
\text { 54365947-54366518 } \\
\text { NHEK cells DNase } \\
\text { I } \\
\text { hotspot: 75095: } \\
\text { 54366045-54370999 }\end{array}$ & $\begin{array}{l}\text { O25615: } \\
\text { 54366091- } \\
54366249 \\
\text { O25610: } \\
54366634- \\
54366977 \\
\text { O25613: } \\
54367707- \\
\text { 54368584 } \\
\text { TSSs: } \\
\text { CHR12-Po397- } \\
\text { R1: } \\
\text { 54366912- } \\
\text { 54366912 } \\
\text { CHR12-Po397- } \\
\text { R2: } \\
\text { 54367584- } \\
\text { 54367584 }\end{array}$ \\
\hline
\end{tabular}

Exact position of this gene is chr12:54356092-54368740. For easiness, genomic region under analysis is divided into smaller portions. Positions are based on UCSC hg19.

TSS, transcription start site; WE, Weizmann evolutionary. 
Supplementary Table 2. Specific CpG dinucleotides methylation status identified from different cell lines in ENCODE

\begin{tabular}{|c|c|c|c|c|c|c|}
\hline \multirow[b]{2}{*}{ Cell line } & \multicolumn{6}{|c|}{$\begin{array}{l}\text { Position } \\
\end{array}$} \\
\hline & $\begin{array}{l}54357408- \\
54357772 \\
\text { Within } \\
\text { CpG1432 }\end{array}$ & $\begin{array}{l}54359712- \\
54359797 \\
\text { Within } \\
\text { CpG1433 } \\
\text { and CpG18 }\end{array}$ & $\begin{array}{l}54360263^{-} \\
54360837 \\
\text { Within } \\
\text { CpG1434, CpG25 } \\
\text { and CpG2.5 (WE) }\end{array}$ & $\begin{array}{l}54363055^{-} \\
54366424 \\
\text { Near to } \\
\text { CpG1436 and } \\
\quad \text { after it }\end{array}$ & $\begin{array}{l}54366760- \\
54367822 \\
\text { Within } \\
\text { CpG1437 and } \\
\text { CpG2 (WE) }\end{array}$ & $\begin{array}{l}54368203^{-} \\
54368640 \\
\text { Within } \\
\text { CpG165 and } \\
\text { CpG2.4 (WE) }\end{array}$ \\
\hline GM12878 & $\begin{array}{l}\text { Unmethylate } \\
\text { d }\end{array}$ & $\begin{array}{l}\text { Mostly } \\
\text { unmethylate } \\
\text { d }\end{array}$ & $\begin{array}{l}\text { Partially } \\
\text { methylated }\end{array}$ & Different & $\begin{array}{l}\text { Partially* } \\
\text { methylated }\end{array}$ & Different \\
\hline H1-heSC & $\begin{array}{l}\text { Mostly } \\
\text { unmethylate } \\
\text { d }\end{array}$ & $\begin{array}{l}\text { Unmethylate } \\
\text { d }\end{array}$ & Unmethylated & $\begin{array}{l}\text { Partially } \\
\text { Methylated }\end{array}$ & $\begin{array}{l}\text { Mostly } \\
\text { unmethylated }\end{array}$ & $\begin{array}{l}\text { Mostly } \\
\text { unmethylated }\end{array}$ \\
\hline $\mathrm{K}_{5} 62$ & $\begin{array}{l}\text { Unmethylate } \\
\text { d }\end{array}$ & $\begin{array}{l}\text { Mostly } \\
\text { unmethylate } \\
\text { d }\end{array}$ & $\begin{array}{l}\text { Partiallya } \\
\text { methylated }\end{array}$ & $\begin{array}{l}\text { Mostly } \\
\text { unmethylated }\end{array}$ & Different & $\begin{array}{l}\text { Partially } \\
\text { methylated }\end{array}$ \\
\hline Hela-S3 & methylated & Methylated & Methylated & $\begin{array}{l}\text { Mostly } \\
\text { methylated }\end{array}$ & $\begin{array}{l}\text { Mostly } \\
\text { unmethylated }\end{array}$ & $\begin{array}{l}\text { Unmethylate } \\
\text { d }\end{array}$ \\
\hline HepG2 & Different & $\begin{array}{l}\text { Partially } \\
\text { methylated }\end{array}$ & $\begin{array}{l}\text { Partially } \\
\text { methylated }\end{array}$ & Different & $\begin{array}{l}\text { Partially } \\
\text { methylated }\end{array}$ & $\begin{array}{l}\text { Mostly } \\
\text { unmethylated }\end{array}$ \\
\hline HuVEC & $\begin{array}{l}\text { Unmethylate } \\
\text { d }\end{array}$ & $\begin{array}{l}\text { Unmethylate } \\
\text { d }\end{array}$ & Unmethylated & $\begin{array}{l}\text { Partiallyc } \\
\text { methylated }\end{array}$ & $\begin{array}{l}\text { Mostly } \\
\text { unmethylated }\end{array}$ & $\begin{array}{l}\text { Unmethylate } \\
\text { d }\end{array}$ \\
\hline
\end{tabular}

Table shows different cell lines (first column) and positions of specific CpG dinucleotides within or near to the predicted CpGIs (first row) in HOTAIR gene.

ENCODE, Encyclopedia of DNA Elements; WE, Weizmann evolutionary.

aOne specific $\mathrm{C}$ nucleotide is unmethylated; other specific $\mathrm{C}$ nucleotides are partially methylated.

bOne specific $\mathrm{C}$ nucleotide is methylated; other specific $\mathrm{C}$ nucleotides are partially methylated.

cTwo specific $\mathrm{C}$ nucleotides are unmethylated; other specific $\mathrm{C}$ nucleotides are partially methylated. 
Supplementary Table 3. The motifs sequences identified by MEME and Mast programs in HOTAIR

\begin{tabular}{|c|c|c|c|c|}
\hline Motifs & Width & Best possible match (strand -) & $\mathrm{p}$-value & Position \\
\hline 1 & 47 & GCGAAAAAGGACCAAGAGGGCGAGACGAGGGAAGAGACCTAGAGAGA & 0.00032 & $\begin{array}{l}\text { Chr12: } 54357805-54357852 \\
\text { (within CpG1432) }\end{array}$ \\
\hline 2 & 40 & TTTACTCTTTCTTTTСТСТСТTTСТTССТСТCTTTTTTTT & 0.00121 & $\begin{array}{l}\text { Chr12: 54360742-54360782 } \\
\text { (within CpG143, CpG2.5(WE)) }\end{array}$ \\
\hline 3 & 39 & СССТСТСССТТТСССТСССТСТСССТТСССССТСССТТТ & 0.00048 & $\begin{array}{l}\text { Chr12: } 54367746-54367785 \\
\quad \text { (within CpG1437, CpG165) }\end{array}$ \\
\hline
\end{tabular}

The motifs sequences are predicted from antisense strand of HOTAIR locus and a specified p-value of the motifs are applied by Mast program.

WE, Weizmann evolutionary. 
Supplementary Table 4. Simple nucleotide polymorphisms in HOTAIR

\begin{tabular}{|c|c|c|c|c|c|c|}
\hline Name (SNP) & Function & Summary & $\begin{array}{l}\text { Reference } \\
\text { allele }\end{array}$ & Strand & Class & Position \\
\hline rs1838169 & nc-transcript variant & $\mathrm{G}>\mathrm{C} / \mathrm{G}$ & $\mathrm{G}$ & - & Single & Chr12:54357495-54357495 (within CpG 1432 ) \\
\hline rs7958904 & nc-transcript variant & $\mathrm{G}>\mathrm{G} / \mathrm{C}$ & $\mathrm{C}$ & + & Single & Chr12:54357552-54357552 (within CpG 1432) \\
\hline rs17840857 & nc-transcript variant & $\mathrm{A} / \mathrm{C} / \mathrm{G} / \mathrm{T}$ & G & + & Single & Chr12:54357757-54357757（within CpG 1432) \\
\hline rs111434707 & nc-transcript variant & $-/ \mathrm{G}$ & G & + & Deletion & Chr12:54357757-54357757（within CpG 1432) \\
\hline rs200062983 & nc-transcript variant & $\mathrm{C}>\mathrm{C} / \mathrm{T}$ & $\mathrm{C}$ & + & Single & Chr12:54357761-54357761 (within CpG 1432) \\
\hline rs35951424 & Intron variant & $-/ \mathrm{A}$ & $\mathrm{A}$ & + & Deletion & $\begin{array}{c}\text { Chr12: } 54357997-54357997 \\
\text { (within HSMM cells DNase I hotspot:66574) }\end{array}$ \\
\hline rs201719283 & $\begin{array}{l}\text { Intron variant- } \\
\text { Splice donor variant }\end{array}$ & $-/ \mathrm{C}$ & $\mathrm{C}$ & + & Deletion & $\begin{array}{c}\text { Chr12:54358048-54358014 } \\
\text { (within HSMM cells DNase I hotspot:66574) }\end{array}$ \\
\hline rs71227278 & $\begin{array}{l}\text { Intron variant } \\
\text { nc-transcript variant }\end{array}$ & -> TTAA & - & + & Insertion & $\begin{array}{c}\text { Chr12:54358048-54358047 } \\
\text { (within HSMM cells DNase I hotspot:66574) }\end{array}$ \\
\hline rs58072355 & Intron variant & $\mathrm{A}>\mathrm{A} / \mathrm{G}$ & $\mathrm{A}$ & + & Single & $\begin{array}{c}\text { Chr12: } 54358443-54358443 \\
\text { (within DNase I hypersensitivity peak clusters 8) }\end{array}$ \\
\hline rs139645979 & Intron variant & -/ACGCACAAG & ACGCACAAG & + & Deletion & $\begin{array}{c}\text { Chr12:54358629-54358629 } \\
\text { (within HSMM cells DNase I hotspot:66574) }\end{array}$ \\
\hline rs10783616 & Intron variant & $\mathrm{C}>\mathrm{C} / \mathrm{G}$ & $\mathrm{C}$ & + & Single & $\begin{array}{c}\text { Chr12:54359220-54359220 } \\
\text { (within active promoter of HSMM cells) }\end{array}$ \\
\hline rs10783617 & Intron variant & $\mathrm{G}>\mathrm{G} / \mathrm{T}$ & $\mathrm{G}$ & + & Single & $\begin{array}{c}\text { Chr12: } 54359387-54359387 \\
\text { (within active promoter of HSMM cells) }\end{array}$ \\
\hline rs376812530 & Intron variant & -/GAAG & - & + & Insertion & $\begin{array}{c}\text { Chr12:54359525-54359525 } \\
\text { (within tandem repeat (AAAG)n) }\end{array}$ \\
\hline rs76o84431 & Intron variant & $\mathrm{C}>\mathrm{C} / \mathrm{T}$ & $\mathrm{C}$ & + & Single & Chr12:54359946-54359946 (within CpG 1433) \\
\hline rs920778 & Intron variant & $\mathrm{C}>\mathrm{C} / \mathrm{T}$ & $\mathrm{C}$ & - & Single & $\begin{array}{c}\text { Chr12:54360232-54360232 } \\
\text { (within CpG1434 and CpG2.5(WE)) }\end{array}$ \\
\hline rs920777 & Intron variant & $\mathrm{C}>\mathrm{C} / \mathrm{T}$ & $\mathrm{T}$ & - & Single & $\begin{array}{c}\text { Chr12:54360429-54360429 } \\
\text { (within CpG 25, CpG1434 and CpG2.5(WE)) }\end{array}$ \\
\hline rs74089839 & Intron variant & $\mathrm{A}>\mathrm{A} / \mathrm{T}$ & A & + & Single & $\begin{array}{c}\text { Chr12:54360561-54360561 } \\
\text { (within CpG 25, CpG1434 and CpG2.5(WE)) }\end{array}$ \\
\hline rs11301759 & Intron variant & $-/ \mathrm{C}$ & $\mathrm{C}$ & + & Deletion & $\begin{array}{c}\text { Chr12:54360613-54360613 } \\
\text { (within CpG 25,CpG1434 andCpG2.5(WE)) }\end{array}$ \\
\hline Rs1899663 & Intron variant & $\mathrm{G}>\mathrm{G} / \mathrm{T}$ & $\mathrm{G}$ & - & Single & $\begin{array}{l}\text { Chr12:54360994-54360994 } \\
\text { (within first active promoter based on Ensembl) }\end{array}$ \\
\hline rs4759314 & Intron variant & $\mathrm{A}>\mathrm{A} / \mathrm{G}$ & $\mathrm{G}$ & + & Single & $\begin{array}{l}\text { Chr12:54361835-54361835 } \\
\text { (within moduleo25607) }\end{array}$ \\
\hline rs17105613 & Intron variant & $\mathrm{C}>\mathrm{C} / \mathrm{T}$ & $\mathrm{T}$ & + & Single & Chr12:54362194-54362194 (within CpG 1435) \\
\hline rs73313155 & nc-transcript variant & $\mathrm{C}>\mathrm{C} / \mathrm{T}$ & $\mathrm{C}$ & + & Single & $\begin{array}{l}\text { Chr12:54362432-54362432 } \\
\text { (within moduleo25607) }\end{array}$ \\
\hline rs73313156 & Intron variant & $\mathrm{G}>\mathrm{A} / \mathrm{G}$ & $\mathrm{A}$ & + & Single & $\begin{array}{c}\text { Chr12:54362915-54362915 } \\
\text { (within moduleo256o8) }\end{array}$ \\
\hline rs5798292 & Intron variant & $-/ G$ & G & + & Deletion & $\begin{array}{c}\text { Chr12:54366274-54366274 } \\
\text { (within } 4 \text { strong Enhancers of NHEK cells) }\end{array}$ \\
\hline rs12427129 & Intron variant & $\mathrm{C}>\mathrm{C} / \mathrm{T}$ & $\mathrm{C}$ & + & Single & $\begin{array}{l}\text { Chr12: } 54367690-54367690 \\
\text { (within CpG 165 and CpG1437) }\end{array}$ \\
\hline rs74089843 & Intron variant & $\mathrm{T}>\mathrm{A} / \mathrm{T}$ & $\mathrm{T}$ & + & Single & Chr12:54368227-54368227 (within CpG 165) \\
\hline rs78894992 & Intron variant & $\mathrm{G}>\mathrm{A} / \mathrm{G}$ & A & + & Single & $\begin{array}{c}\text { Chr12:54368400-54368400 } \\
\text { (within CpG } 165 \text { and CpG2.4(WE)) }\end{array}$ \\
\hline rs75547142 & Intron variant & $\mathrm{C}>\mathrm{C} / \mathrm{T}$ & $\mathrm{C}$ & + & Single & $\begin{array}{c}\text { Chr12: } 54368560-54368560 \\
\text { (within CpG } 165 \text { and CpG2.4(WE)) }\end{array}$ \\
\hline
\end{tabular}

Simple nucleotide polymorphisms (SNPs) were recognized by "dbSNP 147"and positions are based on UCSC hg19. 